\title{
Quality of life assessment in women with stress urinary incontinence following Trans Obturator Tape (TOT) insertion: a prospective study
}

\author{
K. J. Jacob, Megha Jayaprakash*, Anu Cherian
}

Department of Obstetrics and Gynecology, Government Medical College, Thrissur, Kerala, India

Received: 28 July 2017

Accepted: 22 August 2017

\section{*Correspondence:}

Dr. Megha Jayaprakash,

E-mail: meghajayaprakash@yahoo.co.in

Copyright: (C) the author(s), publisher and licensee Medip Academy. This is an open-access article distributed under the terms of the Creative Commons Attribution Non-Commercial License, which permits unrestricted non-commercial use, distribution, and reproduction in any medium, provided the original work is properly cited.

\begin{abstract}
Background: Stress urinary incontinence is a symptom or sign indicating that the woman has involuntary loss of urine associated with exertion in the absence of detrusor contraction. It has a significant impact on quality of life. TOT insertion is a popular procedure being done now. Studies related to quality of life assessment following Trans obturator tape (TOT) insertion is sparingly reported. Objectives of present study were to evaluate the quality of life following TOT insertion in patients with stress urinary incontinence and to assess the post operative complications.

Methods: This is a prospective study done in the Department of Obstetrics and Gynecology, Government Medical College, Thrissur from January 2015 to December 2016. 48 women with Stress urinary incontinence who underwent TOT insertion were included in the study, out of which 30 patients were followed up. The King's Health Questionnaire was used for assessment. Data was analyzed using Epi Info 7 and Microsoft Excel. The statistical analysis was done using student t-test.

Results: At 6 months follow up 86.66\% (26) of patients had significant improvement in quality of life. 2 patients $(6.66 \%)$ had postoperative voiding dysfunction, required recatheterisation, discharged after relief of symptoms. 2 patients $(6.66 \%)$ had urge incontinence, advised medical management and was sent home, showed no improvement even after 6 months. 2 patients $(6.66 \%)$ had continuous incontinence, fistula ruled out. Now they were lost to our follow up. Most common late post operative complication was groin pain. None had mesh erosion, bladder and bowel injuries.
\end{abstract}

Conclusions: TOT is a safe and effective procedure for the treatment of stress urinary incontinence (SUI) which significantly improves the quality of life.

Keywords: Recatheterisation, Stress urinary incontinence, Trans obturator tape

\section{INTRODUCTION}

Stress urinary incontinence is a symptom or sign indicating that the woman has involuntary loss of urine associated with exertion in the absence of detrusor contraction. It has a significant impact on quality of life. It's prevalence varies from $4 \%$ to $35 \%$ depending upon the variation in population studied. ${ }^{1}$ The treatment options include initial conservative therapies (i.e., lifestyle interventions, pelvic floor muscle training, and bladder training), followed by surgery, which is an option for women whose quality of life is still impaired after a diagnosis of genuine stress incontinence. ${ }^{2}$

In France in 2001, Delorme introduced the transobturator sling procedure in humans. ${ }^{3}$

In transobturator tape (TOT) procedure, a small incision is placed in the groins and in the vagina under the urethra. The mesh is placed under the urethra in the correct position without having to pass needles blindly through the retropubic space, as in transvaginal tape (TVT). The 
space that the needle passes through has been extensively studied and has been found to be a very safe space to work in. The mean operative time is significantly shorter in the transobturator sling and risk of bladder injury and of postoperative urinary retention is also considerably lower than other sling procedures. ${ }^{4,5}$

Quality of life is a multidimensional concept, which is assessed in various levels like physical, emotional, social wellbeing of a person and perception of one's own health status.

\section{Relevance of the study}

TOT insertion is a popular procedure being done now. Studies related to quality of life assessment following TOT insertion is sparingly reported. There is lack of long term outcome data6 and very few good quality studies are reported from this part of the world.

\section{METHODS}

This is a prospective study done in the Department of Obstetrics and Gynecology, Government Medical College, Thrissur from January 2015 to December 2016.

48 women with Stress urinary incontinence who underwent Trans Obturator Tape insertion were included in the study, out of which 30 patients were followed up. 22 patients were operated for genital prolapse and stress urinary incontinence. 8 patients were operated for SUI alone. Patients with prior anti-incontinence surgery, prior prolapse surgery, with history of pelvic radiation and neurological disorders affecting lower urinary tract were excluded from the study.

\section{Assessment}

The King's Health Questionnaire was used for assessment. ${ }^{7}$ Patients were asked to fill the questionnaire before the procedure and 6 months after surgery. King's Health Questionnaire has 2 parts. Part 1 consists of general health perception and incontinence impact. Part 2 consists of role limitation, physical limitation, social limitations, personal relationships, emotions, sleep/energy and severity measures. It has scores ranging from 0 to 100 . 0 shows best outcome and 100 shows worst outcome. Data was analyzed using Epi Info 7 and Microsoft Excel. The statistical analysis was done using student t-test.

\section{RESULTS}

$\mathrm{T}$ Mean age was 47.2 years. $63.3 \%$ (19) were in premenopausal and $36.6 \%$ (11) were in postmenopausal age group. $3.33 \%$ (1) was nulliparous and 96.66 (29) were multiparous.

At 6 months follow up $86.66 \%$ (26) of patients had significant improvement in quality of life.
Table 1: Statistical analysis of questionnaire part-1.

\begin{tabular}{|lll|}
\hline $\begin{array}{l}\text { t-test. Paired 2 } \\
\text { samples for the mean }\end{array}$ & $\begin{array}{l}\text { Questionnaire } \\
\text { part-1 }\end{array}$ & $\begin{array}{l}\text { Maximum } \\
\text { score 200 }\end{array}$ \\
\hline & $\begin{array}{l}\text { Preoperative } \\
\text { score }\end{array}$ & $\begin{array}{l}\text { 6 months } \\
\text { follow up }\end{array}$ \\
\hline Mean & 157.9 & 29.16 \\
\hline t-stat & 11.55 & \\
\hline P two tail & 0.00000232 & \\
\hline t critical two tail & 2.01 & \\
\hline
\end{tabular}

2 patients $(6.66 \%)$ had postoperative voiding dysfunction, required recatheterisation and discharged after relief of symptoms. 2 patients $(6.66 \%)$ had urge incontinence, advised medical management and was sent home, showed no improvement even after 6 months. 2 patients $(6.66 \%)$ had continuous incontinence, fistula ruled out. They were being evaluated by urologist and now they were lost to our follow up.

Table 2: Statistical analysis of questionnaire part-2.

\begin{tabular}{|c|c|c|}
\hline $\begin{array}{l}\text { t-test. Paired } 2 \\
\text { samples for the mean }\end{array}$ & $\begin{array}{l}\text { Questionnaire } \\
\text { part-2 }\end{array}$ & $\begin{array}{l}\text { Maximum } \\
\text { score } 600\end{array}$ \\
\hline & $\begin{array}{l}\text { Preoperative } \\
\text { score }\end{array}$ & $\begin{array}{l}6 \text { months } \\
\text { follow up }\end{array}$ \\
\hline Mean & 227.77 & 58.47 \\
\hline t-stat & 5.63 & \\
\hline P two tail & 0.000046 & \\
\hline t critical two tail & 2.041 & \\
\hline
\end{tabular}

Most common late post-operative complication was groin pain. None had bladder injuries and bowel injuries. There were no cases of mesh erosion in the patients followed up in present study.

\section{DISCUSSION}

In this study, $86.66 \%$ (26) of patients had significant improvement in quality of life at 6 months of follow up. In 2004, DeTayrac reported a 1-year cure rate of $84 \%$ with the TOT procedure. ${ }^{8}$ In another study done by Spinosa in 2005 reported subjective complete and partial satisfaction rates of $92.3 \%$ and $4.2 \%$ respectively, following 16.3 months of follow up. ${ }^{9}$ In 2007, Latthe et al. did a similar study and reported the subjective level of complete cure and improvement by patients were $89.6 \%$ and $8.8 \%$, respectively. ${ }^{10}$ Taweel et al. reported a $92 \%$ cure or improvement rate after 12 months and $85 \%$ after 24 months by an objective assessment. ${ }^{11}$

Abdel Fattal et al in 2010, did a randomized prospective single blind study, to compare the 'inside-out' versus 'outside-in' routes for transobturator tape insertion for urodynamic stress incontinence, and to identify independent risk factors for failure at 1 year. The patientreported success rate was $80 \%$ with no statistically significant differences between the groups. The objective cure rate was $91 \%$ with no statistically significant difference between the groups. Previous incontinence 
surgery and preoperative urgency incontinence were significant risk factors for failure of transobturator tape at the 1-year follow up. ${ }^{12}$ Navneet et al in 2012 did a prospective experimental study to see the outcome measures in patients of SUI treated with transobturator sling. They reported that TOT application was successful in $93.2 \%$ cases in this study and it failed in $6.8 \%$ cases. $^{2}$ So present study is comparable with other studies.

In this study, at 6 months follow up none had bowel or bladder injury. There was no cases of mesh erosion in the patients followed up in present study. Mesh erosion is a late complication, which usually happens after 2 years. In this study, patients were followed up only upto 6 months.

\section{CONCLUSION}

TOT is a safe and effective procedure for the treatment of stress urinary incontinence which significantly improves the quality of life.

\section{ACKNOWLEDGMENTS}

Authors would like to thank colleagues in the Department of Obstetrics and Gynecology, Government Medical College, Thrissur for their support during study.

\section{Funding: No funding sources}

Conflict of interest: None declared

Ethical approval: Not rquired

\section{REFERENCES}

1. Studd J, Tan SL, Chervenak FA. Current Progress in Obstetrics and Gynecology-Volume 3. Tree life media;2015.

2. Magon N, Chopra SV. Transobturator tape in treatment of stress urinary incontinence: it is time for a new gold standard. North Am J Med Sci. 2012;4(5):226.

3. Delorme E. Transobturator urethral suspension: Mini-invasive procedure in the treatment of stress urinary incontinence in women. Prog Urol. 2001;11:1306-13.

4. Howard WJ, Rock JA. Te Linde's Operative Gynecology. $11^{\text {th }}$ Ed. Philadelphia: Wolters Kluwer, United States; 2015.
5. Cundiff GW, Azziz R, Bristow RE. Te Linde's Atlas of Gynecologic Surgery. Philadelphia, PA : Wolters Kluwer Health/Lippincott Williams \& Wilkins, United States;c2014.

6. NICE. Urinary incontinence in women: management (CG 171). 2013. Available at https://www.nice.org.uk/guidance/cg171.

7. Reese PR, Pleil AM, Okano GJ, Kelleher CJ. Multinational study of reliability and validity of the King's Health questionnaire in patients with overactive bladder. Qual Life Res. 2003;12(4):42742.

8. DeTayrac R, Deffieux X, Droupy S, ChauveaudLambling A, Calvanese-Benamour L, Fernandez H. A prospective randomized trial comparing tensionfree vaginal tape and transobturator suburethral tape for surgical treatment of stress urinary incontinence. Am J Obstet Gynecol. 2004;190:602-8.

9. Spinosa JP, Dubuis PY. Suburethral sling inserted by the transobturator route in the treatment of female stress urinary incontinence: Preliminary results in 117 cases. Eur J Obstet Gynecol Reprod Biol. 2005;123:212-7.

10. Latthe PM, Patodi M, Constantine G. Transobturator tape procedure in stress urinary incontinence: UK experience of a district general hospital. J Obstet Gynecol. 2007;27:177-80.

11. Taweel WA, Rabah DM. Transobturator tape for female stress incontinence: Follow-up after 24 months. Can Urol Assoc J. 2010;4:33-6.

12. Abdel-fattah M, Ramsay I, Pringle S, Hardwick C, Ali H, Young D et al. Randomised prospective single-blinded study comparing 'inside-out' versus 'outside-in' transobturator tapes in the management of urodynamic stress incontinence: 1-year outcomes from the E-TOT study. BJOG. 2010;117:870-8.

Cite this article as: Jacob KJ, Jayaprakash M, Cherian A. Quality of life assessment in women with stress urinary incontinence following Trans Obturator Tape (TOT) insertion: a prospective study. Int J Reprod Contracept Obstet Gynecol 2017;6:4508-10. 